\title{
THE THEORY OF J. M. KEYNES TO CLARIFY THE PUBLIC-PRIVATE PARTNERSHIP ESSENCE AND PARTICULARS
}

\author{
Alla Suriak \\ Associate Prof. PhD, Lesia Ukrainka Eastern European National University, \\ e-mail: avsuriak@gmail.com, orcid.org/0000-0002-3094-9941, Ukraine \\ Mirosława Skalik \\ $\mathrm{PhD}$, Polonia University in Czestochowa, \\ e-mail: m.skalik@ap.edu.pl,orcid.org/0000-0002-6259-4794, Poland \\ Blaise Hameni \\ Dr, John Pall II International University of Bafang, \\ e-mail: bhameni@yahoo.fr, orcid.org/0000-0002-9922-7947, Cameroon
}

\begin{abstract}
The public-private partnership nature and its particulars have been studied and clarified herein taking into consideration the theory of J. M. Keynes, in particular, when reffering to the private entrepreneur's behavoir as to the employment and investment activities to create the effective demand and economic development.

Keywords: theory of J. M. Keynes, employment, investment, public-private partnership, public-private partnership nature, investment activities in the public-private partnership, and economic development
\end{abstract}

DOI: http://dx.doi.org/10.23856/2407

\section{Target Setting}

The modern development of the market economy is exceptional and unique in each country. Focusing on the economic and social stability, economic ways and means of the development and growth, each country makes its own choice based on its realities, vision and understanding of the situation of own experience including the negative ones. To speed up the progressive trends and results, the review and study of the market management theories are very important to search replies to questions that have arisen in the course of practice in these theories.

\section{Actual Scientific Researches and Issues Analysis}

The private entrepreneur's behavior within the market economy and the possible cooperation between the state and business to implement the public-private partnership were studied in the works of many scientists. They are: J. Keynes, J. Buchanan, V. Varnavskyy, M. Weber, T.Veblen, E. Durkheim, J. Commons, D. Nord, G. Schmoller B., R. Coase, M. Meyer, L. Fabius, J. Hodgson, E. Furubotn, R. Richter, E. Ostrom, G. Tullock, T. Eggertsson, T. Bredgard, J. Coleman, R. Putnam, R. Antonov, A. Amosha, Y.Bazylevych, S.Varnaliy, O.Vikarchuk, A. Halchynskyi, V. Heiets, N. Hrazhevska, V. Dementiev, A. Gritsenko, B. Sikora, R. Pustoviit, Y. Kuzmin, T.Yefymenko, S. Mochernyi, A. Chukhno, E. Cherevykov, and others. 


\section{Remaining Challenges}

Determining the public-private partnership nature and its characteristics, the analytical treatment of many studies confirms the fact that the private entrepreneur's behavior was not taken into account within the conditions of the market economy. However, J. Keynes analyzed it in details and determined it as a significant element of the public-private partnership development through the increased employment and investment activities in the economic advancement.

\section{The Purpose of the Article}

It is determined by the thorough study of the theory of Keynes concerning the private entrepreneur's behavior within the economy, particularly, issues concering the employment, social ideas, investment funds with their evaluation and goal realization, as well as the the search for the partners to carry out the investment activities. With regard to this, the definition of the public-private partnership nature and characteristics shall be given. As a result, the public-private partnership and economic development will be stepped up.

\section{Study Highlights}

It was in studies revealing that the Keynesian theory became one of the fundamental theories of the market economy (Bazylevych, Ilin, 2011: 3-4). Now, it is relevant too and motivates both the theoreticians and practitioners deeply and carefully reread the work "The General Theory of Employment, Interest and Money" once again. Although, J. Keynes has warned that the power of vested interests is greatly exaggerated in the comparison with the constant increas of the impact of ideas (Keynes, 2002: 149). It leads us to the conclusion that any idea must be both new and focused on the welfare. Therefore, we will not only detect the grounds of the vision of the public-private partnership already established in the theory of $\mathbf{J}$. Keynes, but also we will try to find there those common aspects of the cooperation between the state and business. Those aspects, which will be able to persuade the business or according to J. Keynes, the entrepreneurs, to cooperate with the state authorities as the spokespersons of the state and its citizens for a long term and have the idea, which is broader than simply a guarantee of profits or privileges.

The equity contribution ensuring the state development is based on the assumption proving the dependence of the aggregate real income growth on the increase in the employment. Psychology of the society is that any growth of the aggregate real income causes the increase in the total consumption. Therefore, employers would have some losts if all the increased employment was aimed at the meeting of he increased demand and at the current consumption items. To maintain any given level of the employment, it is required to have current investments, absorbing the excess of the aggregate production above those, which any society wants to consume at a given level of the employment (Keynes, 2002: 12). Continueing to reveal the equity contribution, J. Keynes states that business revenues will be lower than those, which are necessary to make the enterpreneurs to focus their activities on the achievement of this level of employment if investments are not increasing. He also concludes that at the present value of the index, which we call the tendency of the society to consume, the equilibrium level of the existing employment, the level at which entrepreneurs generally do not aspire to expand or to reduce the employment will depend on the value of current 
investments (Keynes, 2002: 12). The value of current investments in its turn depends on what we call the inducement to engage in investment activities being closely connected with the ratio between the schedule of the capital marginal efficiency and a set rate of the credit interest with different terms of credit repayment and degrees of risk (Keynes, 2002: 12). According to J. Keynes, the employer personally decide the type of the existing capital equipment will be used in each case. He also underlines that the company owning any capital equipment are concerned to combine it with the employment of a great number of workers (Keynes, 2002: 17). Any production increase or decrease can be examined in a firm or industry, which produces homogeneous products. However, when considering the aggregate activities of all the firms, we can consider that only the level of employment coincides with the number of some available equipment (Keynes, 2002: 17). The employment rate correlating with the capital may be the acceptable indicator of the volume of products manufactured in the economy for given amounts of the capital equipment. J. Keynes comes from the fact that these two values are changing in the same direction, though they do not always observe the same proportions in a parallel movement (Keynes, 2002: 17) J. Keynes suggests to measure changes in the current production output using the employing workers who use the existing equipment (Keynes, 2002: 18).

The first thing that should be noted is that J. Keynes considers the features of the decision-making by the businesspersons grounding on their assumptions and divids them into two groups. The first one - the entrepreneur plans the finished product price. The second group of assumptions on which the entrepreneur makes the decision involves issues concerning the structure of future earnings if such a businessperson will increase own capital assets to buy or produce the finished goods personally. Such types of calculations as well as the decision- making form either short-term or long-term assumptions (Keynes, 2002: 20). Thus, entrepreneurs must see the structure of their incomes to make a decision for the long term.

J. Keynes defines the effective demand as "the total income (or revenue) expected to be received by the entrepreneurs (including amounts that they will pay the owner of the other factors of production, as incomes) in accordance with the level of the current employment which they decide to organize."

Regarding the investments, J. Keynes concludes that the size of new investments should always be slightly larger than any disinvestments (objects made before) to fill the gap between the net income and consumption. This problem is becoming more acute in the capital increase. Moreover, new investments will be in sizes that exceed the current investments only when you can expect that the cost of such consumptions will grow in the future. Reducing the tendency to the consumption in a given time can only be adapted to social benefits if it increases (Keynes, 2002: 21).

J. Keynes indicates that the public attitudes realize the necessity of some aggravation in times to come, perhaps, only in cases when it deals with the public investments, such as the construction of roads, houses, etc. The customary non-support of job plans meaning the increase in the employment through the investments carried out by the central government and municipal authorities lies in the fact that it creates a source of difficulty in the period ahead (Keynes, 2002: 51).

Any investment activity for some extended lengths of time is called by J. Keynes as a very difficult decision because of some high risks and complexity of the future profit calculations. According to him, to make a professional investment is most complicated task, but only for those people, who make a deal with long-term investments, and are able to 
contribute to the public interests more than others are. However, in practice, committees, boards or banks managing the investment funds often criticized them (Keynes, 2002: 74).

Thus, taking into account the approaches given by J. Keynes, we can argue that the public-private partnership as a modern form of the economic and investment activities is a form of impact on the employment. It is very necessary for the business (entrepreneur) to get profits and for the state to develop its economy.

The public-private partnership as a special phenomenon of the modern management and at the same time as a form regulating the economy should be based on the state and entrepreneur's behavior having been practically and theoretically studied by J. Keynes. He has taken into account the effective demands and assumptions as to the future income conditions of the investment effectiveness in the long term, the role of employment for the economy and the entrepreneur's results, the role of investment for the state and its economic development in future periods as well as the entrepreneur's behavior and place in society (Blaug, Keynes, Maynard, 2008).

Therefore, determining the public-private partnership nature, it is necessary to clarify its objectives, goals of its members offering the public-private partnership mechanisms and role of the government regulating the cooperation between the state and businesses to be clear when we talk about its direction and essence in fact, as well as the form of its implementation.

Our modern economic literature sources involve many different definitions of the public-private partnership. Scientists, economists and jurists differently explain and ground it. The most common in the economic literature sources and often used by the researchers is the explanation of this phenomenon given by Varnavsky V. G. He consideres that the modern sense of any partnership of the state and the private sector means the institutional and organizational alliance between the public authorities and private businesses. Such an alliance assists to implement national and international, large and socially important projects in a wide range of activities: from the development of strategic industries and $\mathrm{R} \& \mathrm{D}$ up to the ensurence of public services (Varnavskyi, 2017). The definition is practically full and includes not only the essence, but also the features, mechanisms, enteties, purposes and scopes of the public-private partnersghip.

Most public-private partnerships are oftern defined as a mutually beneficial partnership among some public and private entities to get profit and social benefits in the fields of economy. Such a partnership grounds on the combination of the cash and other deposits of the other partners, and involves some sharing of risks allowing the partial exemption of the private subjects from the business risks (Halimovsky, 2011: 25). It focuses on the mutual benefitial cooperation and partnership among members and their goals achieving through the joint efforts.

In general, interpretating the public-private partnership essence, the attention is focused on the justification of the use or implementation of public-private partnership as the acceptable mutual activities in favourable conditions and prospects for its each participant. The ability to make a profit by providing these services is beneficial for the public-private partnership and state. The state has some benefits when it involves funds as the result of such a cooperation with the public private partners, as the state needs them at this time to reralize own functions, and sometimes it (the state) transfers some of own functions to its private partners in terms of the distribution of risks.

The public-private partnership is also determined as either the cooperation or integration of the state with the private sector by combining their tangible and intangible resources mainly in the areas characterizing by the inefficiency of the government 
(Gerasymenko, 2010: 11). As we can consider, it focuses on the areas where the publicprivate partnership will be a collaboration of the public and private sectors. Factually, it can be possible only in the areas where the state requires some management and financial performance being currently impossible for it at that time. However, the purpose, importance and place of the private sector interests are not specified and defined. Therefore, we can assume that a theoretical definition of the public-private partnership will help the private entrepreneur to consider the cooperation with a state in the form of the public-private partnership as a promising form of business in the economically disadvantageous long run.

These theoretical aspects of the generalization mentioned above have been taken into account in the Law of Ukraine "On Public-Private Partnership". It stipulates the public-private partnership as the cooperation between the State of Ukraine, the Autonomous Republic of Crimea, local communities represented by the respective state authorities and local selfgovernment (government partners) and legal entities, except the state and municipal enterprises, or individuals - entrepreneurs (private partners), which is based on the agreement (Law of Ukraine "On the Public-Private Partnership",2010).

When considering the public-private partnerships, the economists often take into account the views of sociologists, jurists who accentuate own attention on public-private partnership as a partnership documented with clearly defined rights and responsibilities of its partners, the implementation mechanisms, and responsibilities of the parties. Such a viewpoint also extends the public-private partnership characteristic features, and is not contrary to the theory of J. Keynes as to the behavior of the private entrepreneurs carrying out any investment activities being reasonable, responsible and calculated. Projects required by the society are performed within the framework of the modern economic advancement (The Program of the Investment and Innovative Activities in Ukraine, 2011). All of the mentioned above significantly clarify the understanding of the economic and social feasibility of the publicprivate partnership and provide a guarantee of the public support in its social orientation being sisnificantly able to contribute to the expected profits.

All definitions as to the public-private partnership essence are focused on the fact that the public-private partnership is the cooperation between the state and business. It is also considered as some mutually beneficial activities undertaken to implement projects, tasks where contributions are combined, risks are distributed, and benefits are gained, including the transfer of state functions to the private sector.

The public-private partnership special features include some voluntariness, publicity, and win-win both for the state and for the private sector, legalization of resources or other contributions of the parties, pre-defined rights, responsibilities, risks, results, interests of the parties and some mutual coordination with the effective implementation of projects and tasks in those areas, which are important for the society.

From this perspective, modern definitions of the public-private partnership nature and the theory of J. Keynes as to the private entrepreneur's behavior and tasks of the state in the advanced economy permit us to considere a public-private partnership as the coordination of some investment activities of the state and private entrepreneurs as partners in the long-term economic and social development.

With regard to this essence detailing, we can assert that features of the state partnership with business are given below.

First, the public-private partnership is an investment activity of partners, but is not their mutual investment activity. 
Secondly, it is a coordination of partners' actions in each project, which is legally enforceable and regulates the activity of each of them.

Fimnaly, each collaborate being the participant of these long-term partnerships implements socially significant projects through the increased employment and contributes benefits to the economic development of of the society.

The increase in the employment is achieved through the implementation of the comprehensive partnership between the state and the entrepreneur, where each of the partners does not set out to contribute to the growth of the employment, but the realization of their investments in the project just increases the employment. Moreover, it positively impinges on the propensity to consumpt and save, and increases the aggregate demand under the mechanism grounded by $\mathrm{J}$. Keynes for the economic development and the special role of the state in it.

The role of the organizer and the declarant of the specific project of the partnership belongs to the state in the public-private partnership. A share of the private partner may be different. According to the methodology of the World Bank, the projects of the public-private partnership are considered as projects having been realized and based on the management, lease, concession, and sale of assets agreements. This project is considered as a public-private partnership if the private partner involved in its implementation and sales at least $25 \%$ and assets in the project $-5 \%$ of the shares belonging to the private owners (Ukraine - Private Infrastructure Projects - The World Bank \& PPIAF, 2016). Such an approach to the private partner's share in the project makes an additional argument to understand the public-private partnership as a set of the coordinated actions under the investment activities of the state and private entrepreneurs as partners in the long-term economic and social development is not reflected in the Ukrainian legislation. However, there is clearly specified that the objects of the public-private partnership cannot be privatized for the duration of the agreement and the objects of the public-private partnership cannot be objects of any privatization. That does not allow the use of the public-private partnership for the redistribution of any property and promotes a responsible decision on the part of the private partner in the project as a long-term investment with a reliable partner - state. The World Bank monitoring of the public-private partnerships by its methodology can be considered as an illustration of the real status of the public-private partnership development in the world and a reference point for the development of the public-private partnership in Ukraine (Private Participation in Infrastructure Database Expanded Methodology).

The public-private partnership management practice as well as the international experience prove that the mechanisms chosen to perform the cooperation among the public authorities and private partners of each country depends on the status and existing factors of its economic development. Its managerial culture, social responsibility for the national business traditions and levels of the national legal system development, the state guarantees and responsibility for the compliance with the economic rights and freedoms are also important herein (Institute for Public-Private Partnerships). However, when choosing a joint mechanism of the public-private partnership, the cooperation of its members has to ensure each partner the opportunity to reach their goals, and project objectives according to $\mathrm{J}$. Keynes.

The private partner can expand its activities and fill it with new content in a partnership with the state, despite to solve more and more problems in the constant search for ways to maximize own profits. J. Keynes warned that not only profits determine the entrepreneur's behavior in his work. Carying out the joint activity with the state aimed at the development of 
its economy and the welfare of its citizens, the private partner can expect to get the access to state property. Moreover, any partner obtains other benefits like tax benefits, to attract monetary funds together with budget funds as a share of the state in the partnership. As a result, it stimulates business development, overcomes barriers to entry in new markets for goods and services. This business is a compelling argument and a stimulus to invest and find some increasing profitability and guarantees to save the invested capital.

Achieving a common goal of the public-private partnership with a clear legal regulation and complete fulfilment of obligation by each partner will not be manifested in the countervailing interests. The reconciliation of the private entrepreneur and public authority will have been regulated before the realization of such a partnership. It is the stage when the partner is selected through the competition analyzing the private partner compliance with the objectives of the project and its ability to provide the expected benefits. The public-private partnership with the state is the coordination of the investment activities carrying out by the state and the private entrepreneurs jointly as partners in the long-term economic and social development. Therefore, multidirectional interests are impossible in the public-private partnership. Partners become those candidates who have the partner's goal as own purpose. A profit of the private partner should be the task of the state and reward for the successful investment and socially significant results.

When choosing a partner, the state is obliged to provide such conditions for the private partner to satisfy those interests, which have been declared in the partnership agreement and to invest, as it has been prescribe herein. Interests of the private partner will be satisfied only after the satisfaction of the public interests whose guarantor is the state, but in this partnership - the employer and the state.

Therefore, the public and private sectors and their cooperation cannot be considered in the case of the public-private partnership. The partnership is possible only between an entrepreneur and a public authority both as the state representative and the spokesperson of the society.

According to international practices, the state initiates the long-term cooperation, defines the requirements for the future private partners, and determines the results of the partnership (Public-Private Partnerships in Europe - Before and During the Recent Financial Crisis, 2010). However, if the state sees an opportunity to organize and coordinate the private partner's activities out of the partnership agreement in case of the public-private partnership or to change terms when it is imperfect, then to find a private partner for the long-term investment cooperation will be a challenge. It shall become a cause of the non-proliferation of the public-private partnership as a new way of the state economic development and investment growth.

Thus, the overall aim of the public-private partnership and its main features became the ground of the consistent use of public and private resources to solve problems of the state and society through the involvement of the private investors and efficient use of the combined capabilities and maximization of benefits gained in the results of mutual cooperation of both parties. So, the state uses this partnership as a tool to get investments, to obtain the meaningful social effect, to reduce the rate of unemployment, to improve the living standards and economic development.

The state can add the consultative functions as a partner of the public-private partnership for its further development. It will be perfomed by the relevant ministries and agencies, or specially authorized bodies (The Briefing Note of the National Institute for Strategic Studies under the President of Ukraine). Main areas of their work should be the 
development and implementation of the investment policy through the public-private partnerships, monitoring the performance of the executive bodies and local authorities in the implementation of the public-private partnerships and its agreements.

\section{Findings and Conclusions}

1. Based on the theory of the behavior of a private entrepreneur and tasks of the state in the economy determined by J. Keynes, we concluded that any public-private partnership is the coordination of the investment activities of the state with private entrepreneurs as partners in a long-term economic and social development.

2. The features of the partnership between the state and business is that the publicprivate partnership is initially an investment activity of each partner, and is not their joint investment activities. Then, the coordination of their actions in each project is legally enforceable and regulates the activity of each partner individually and finally, each partner participating in this long-term partnership implements socially significant projects through the increased employment favourably contributes to the economy and society.

3. The partnership mechanism control should be practically performed, but the monitoring of the partnership investment results by each partner shall have been discussed and agreed by the partnership partners before its implementation. The long experience of countries that have already implemented some projects of the public-private partnership having had the public approval and recognition, confirms it.

4. The state responsible attitude is the basis for the mutually beneficial investment partnership, which determines clearly and in details the ways of the distribution and execution of investment obligations by the partners under the agreement. The public-private partnership effectiveness for each of its partners is to increase the employment in the country creating conditions for the promotion of the social economic development strategy and accelerating the economic growth of the country.

5. Successful global and national projects of the public-private partnership will give business some confidence concerning possibilities and benefits of the cooperation with the state as a reliable investment collaborate for the long term.

\section{References}

Bazylevych, V. D., Ilin, V. V. (2011). Philosophy of Economy. History. [Monographs]. Kyiv: Znannia, 1198 p. [in Russian].

Blaug, M., Keynes, J., Maynard, J. (2008). 100 Great Economists before Keynes: An introduction to the lives \& works of one hundred great economists of the past. St. Pitersburg: Economicus, 121 [in Russian].

Gerasymenko, O.A. (2010). PPP Development within the Management of the Regional Educational System. [Abstract]. Belgorod, 27 p. [in Russian].

Halimovsky, Y.A. (2011). The State-Private Partnership in the Subjects of the Russian Federation. Gaps in Russian legislation, No.14,12-18. [in Russian].

Institute for Public-Private Partnerships. (n.d). [Electronic resource]. Retrieved from http://www.ip3.org/ip3_site/2013-public-private-partnership-trends.html. [in English].

Keynes, J. M. (2002). The General Theory of Employment, Interest and Money. (N. N. Liubimov, trans.; L. P. Kurakov, ed.). Moscow: Gelios ARV, 352. [in Russian]. 
Law of Ukraine "On the Public-Private Partnership",1.07.2010, No.2404-VI. [Electronic resource]. Retrieved from http://www.nau.ua/druk.php?name=332930-01072010-0.txt. [in Ukrainian].

On the Development of the Public-Private Partnership as a Mechanism for the Activation of Investment Activities in Ukraine. (n.d). The Briefing Note of the National Institute for Strategic Studies under the President of Ukraine. [Electronic resource]. Retrieved from http: //www.niss.gov.ua/articles/816/. [in Ukrainian].

Private Participation in Infrastructure Database Expanded Methodology. (n.d). [Electronic resource]. Retrieved from http://ppi.worldbank.org/documents.pdf. [in English].

Public-Private Partnerships in Europe - Before and During the Recent Financial Crisis. (2010). Economic and Financial Report. European Investment Bank. [Electronic resource]. Retrieved from http://www.eib. org/epec/resources/efr_epec_ppp_report1.pdf. [in English].

The Program of the Investment and Innovative Activities in Ukraine, 02.02.2011, No. 389 Electronic resource]. Retrieved from http://zakon4.rada.gov.ua/laws/show/389. [in Ukrainian].

Ukraine - Private Infrastructure Projects - The World Bank \& PPIAF. (2016). [Electronic resource]. Retrieved from http://ppi.worldbank.org/explore/ppi. [in English].

Varnavskyi, V. G. (2017). Conceptual Econiomic and Legal Fundamentals of the Concessional Activities [Electronic resource]. Retrieved from http://www.Irex.ru/press/pub/polemika/13/var. [in Russian]. 